\title{
European Financial Law Review
}

\section{Formerly: European Financial Services Law}

\section{Editor-in-Chief: Barry A.K. Rider \\ Executive Editor: Jason D. Haines}

European Financial Law Review provides an authoritative forum for the analysis and discussion of the law, regulation and practice relating to all aspects of the financial world in Europe and addresses their impact on the world financial community from a distinctly European perspective. The coverage of the journal encompasses the law relating to the raising and trading of securities, whether equity, debt or municipal, the regulation of intermediaries, the governance and operation of financial markets and the financial services industry and all legal aspects of the protection and handling of financial wealth. Finally, the journal is concerned not only with the facilitation of enterprise and the flow of funds, but also the tendency to place financial regulations at the fore in the fight against serious economic crime.

The subjects covered include:

- Securities Regulation;

- Banking and Financial Services Law;

- Compliance;

- Avoidance and Management of Conflicts of Interest;

- Securitisation of Debt;

- Prevention and Control of Money Laundering;

- Financial Crime;

- International Services Law

European Financial Law Review provides a unique 'one stop' source for all those concerned with the management and stewardship of other people's wealth and is primarily aimed at lawyers, accountants, financial intermediaries and regulators.

The journal is edited at the Institute of Advanced Legal Studies and supported by a distinguished international board of editors.

European Financial Law Review supersedes European Financial Services Law, which over the last six years has contributed a great deal to the analysis of securities regulation within a European context.

Kluwer Law International, The Hague

2000, Volume 7 (6 issues)

Price: NLG 785.00/USD 374.00/GBP 240.75

ISSN: $1350-2018$

Please contact our office at one of the following addresses or order from your bookseller: For Europe and Rest of World:

Order Department, Kluwer Law International,

Distribution Centre, PO Box 322.

3300 AH Dordrecht, The Netherlands

Tel: +31 (0)786546451 - Fax: +31 (0)786546474

Freephone in the UK: 0800963955

email: sales@kli.wkap.nl

For USA, Canada, Central and South America: Order Department, Kluwer Law International, 675 Massachusetts Avenue, Cambridge, MA 02139, USA

Tel: (617) 3540140 - Fax: (617) 3548595 Toll free in the USA: $(800) 5778118$ email: sales@kluwerlaw.com

Visit our website at http://www.kluwerlaw.com 


\section{European Business Law Review}

General Editor: Mads Andenas

Consultant Editor: Laurence W. Gormley,

Dept. of European \& Economic Law, Rijksuniversiteit Groningen

Developments like the completion of the Single Market, the adoption of the Treaty on European Union, the opening up of the European Economic Area, and the emergence of the Central and Eastern European markets make it vital for all legal practitioners and academics concerned with commercial and transnational law to have access to up-to-date information on the laws governing business throughout the whole of Europe. European Business Law Review offers current, authoritative information on a wide range of issues and developments in European business law. Written by a distinguished international team of legal practitioners and academics, European Business Law Review proves an invaluable source of current information, practical analysis, and expert guidance for all lawyers, advisers, and researchers dealing with European business law on a regular basis.

\section{Every month European Business Law Review includes}

- analytical articles offering incisive investigations and practical analysis of topics of current importance;

- country reports highlighting key issues from different European countries;

- Eurobrief, containing concise summaries of the latest European Community Directives, as reported in the Official Journal, and details of relevant communications from key European institutions;

- case notes on important recent cases from the European Court of Justice, the Court of First Instance and various national courts; and

- reviews of the latest literature on areas of European business law.

European Business Law Review provides a regular service of opinions and new information, offering practical analysis and guidance on a broad spectrum of topics relating to commercial law in Europe. It covers legal developments in the European Community, the EFTA countries, and the new democracies of Central and Eastern Europe, and also offers an insight into the legal aspects of European trade with non-European countries.

Kluwer Law International, The Hague

2000, Volume 11 (11 issues)

Price:NLG 907.00/USD 432.00/GBP 278.25

ISSN: 0959-6941

Please contact our office at one of the following addresses or order from your bookseller:

For Europe and Rest of World:

Order Department, Kluwer Law International,

Distribution Centre, PO Box 322

3300 AH Dordrecht, The Netherlands

Tel: +31 (0)786546451 - Fax: +31 (0)786546474

Freephone in the UK: 0800963955

email: sales@kli.wkap.n!
For USA, Canada, Central and South America: Order Department, Kluwer Law International, 675 Massachusetts Avenue,

Cambridge, MA 02139, USA

Tel: (617) 3540140 - Fax: (617) 3548595

Toll free in the USA: (800) 5778118

email: sales@kluwerlaw.com 


\section{EUROPEAN BUSINESS ORGANIZATION LAW REVIEW}

Established in 2000

European Business Organization Law Review is published in cooperation with the T.M.C. Asser Instituut, Institute for Private and Public International Law, International Commercial Arbitration and European Law, The Hague, The Netherlands. The T.M.C. Asser Instituut is responsible for the promotion of research and education in international law, particularly by carrying out research programmes and setting up documentation projects in the fields covered by the Institute.

\section{Publisher AND DISTRIBUTION}

European Business Organization Law Review is published by T.M.C.ASSER PRESS, P.O.Box 16163, 2500 BD The Hague, The Netherlands. Tel.: +31(70)3420800, Fax: +31(70)3420801, E-mail: press@asser.nl and website www.asserpress.nl. It is distributed for T.M.C.ASSER PRESS by Kluwer Law International, The Hague, The Netherlands

\section{SUBSCRIPTIONS}

Subscription to European Business Organization Law Review includes 4 issues a year. Volume 1 (2000) will comprise three issues and is offered to subscribers at 50 percent of the full subscription rate. This special introductory price amounts to NLG 199.00/EUR 90.50/USD 90.00 (incl. postage and handling). Subscriptions and requests for specimen copies should be sent to Kluwer Law International, P.O.Box $85889,2508 \mathrm{CN}$ The Hague, The Netherlands.

\section{RECOMMENDED CITATION: EBOR}


VOL. I 2000/1

\section{Contents}

EDITORIAL

\section{ARTICles}

WOLFGANG ScHŌn, The Concept of the Shareholder in European

Company Law

FRÉDÉRIC JENNY, Economic Analysis, Anti-trust Law and the Oligopoly Problem

KATHARINA PISTOR, Patterns of Legal Change: Shareholder and Creditor Rights in Transition Economies

FRANS VANISTENDAEL, The Making or Br(e)aking of Europe or the Challenges for a European Tax Policy

\section{CASE Notes}

PETER BEHRENS, International Company Law in View of the Centros decision of the ECJ

VANESSA EDWARDS, Case-law of the European Court of Justice on Freedom of Establishment after Centros

\section{BOOK REVIEWS}

Vanessa Edwards, EC Company Law (Mathias Habersack)

Doris Hildebrand, The Role of Economic Analysis in the EC Competition Rules (Joachim Jickeli) 